\title{
The Effectiveness Of Multimodal Approaches In Learning
}

\author{
Mochamad Bayu Firmansyah \\ Pendidikan Bahasa dan Sastra Indonesia, Fakultas Pedagogi dan Psikologi, \\ Universitas PGRI Wiranegara Pasuruan, Jawa Timur, Indonesia \\ firmansyahbayu970@gmail.com
}

\begin{tabular}{ll}
\hline Article History & Received : January $7^{\text {th }} 2021$ \\
& Revision : February $11^{\text {th }} 2021$ \\
& Publication : March 30th 2021 \\
\hline
\end{tabular}

\begin{abstract}
This study aims to test the effectiveness of a multimodal approach in learning. The method used in this study is an experimental research method whose implementation uses a quasi-experiment type. The steps of implementing the effectiveness test, namely (1) determining the control group and the experimental group, (2) conducting the pretest, (3) carrying out learning in the control and experimental class, (4) conducting the postest, and (5) analyzing the experimental test results. The multimodal approach has been tested through the t-test to improve students' literary psychological analysis skills. The results of the effectiveness test showed a significant difference in students' psychological analysis abilities in general between the post-test scores of the control class and the experimental class $(p=0.00<0.05)$. This shows that the two variances are not the same, so the variance to compare the population average (t-test for Equality of Means) in the t-test test must be based on equal variance not assumed. At the equal variance not assumed, a t value of 8.114 was obtained and a significance level of Sig. (2-tailed) of $0.000<0.05$, $p=0.000$. These results indicate that $p<0.05$, means that there is a significant difference between groups of students who get treatment using a multimodal approach. Thus, there is a significant difference in student learning outcomes between the experimental class with the multimodal approach compared to the control class with conventional methods. The above analysis results show that Ho is rejected because of the significance level of Sig. (2-tailed) of $0.000<0.05$, while H1 was accepted because there was a significant difference between the increase in student learning outcomes in the experimental class and the control class.
\end{abstract}

Keywords: Effectiveness, Multimodal Approach, Learning.

\section{INTRODUCTION}

A multimodal approach is an analytical approach oriented towards social semiotics in revealing modalities (language, images, music, sound, and movement) as producers of text and discourse. Text and discourse as language contexts are socially constructed. Language is positioned as a social sign (Coccetta, 2018; Mochamad Bayu Firmansyah, 2021; Montoro, 2015). Language is associated with human experience in social interaction. In a series of social actions, the construction 
of a systemized reality is based on the construction of meaning in which reality is interpreted. Therefore, the next meaning is twofold depending on the social semiotics and the series of information contained in the language. The multimodal approach focuses on the representation of understanding and the production of meaning through discourse from various modalities (language, images, music, sound, and movement) (Mochamad Bayu Firmansyah, 2021; Hermawan, 2013; Jewitt, 2008; Nina Nørgaard, 2009). The multimodal approach focuses on aspects of discourse, aspects of design, aspects of production, and aspects of distribution by paying attention to the semiotic resources that are deployed in various modalities. First, focus on aspects of discourse, namely a multimodal approach in learning that focuses on social knowledge built on several parts of reality. This aspect of reality is the social context presented implicitly and explicitly by the goals of social actors. Second, focus on the design aspect, namely the conception of the expression side and vice versa the expression from the conception side. Conception from the expression side reflects the context of the situation presented and vice versa from the conception side expression becomes a modality of action formed socially. Third, focus on the production aspect, which refers to the organization of expressions from basic material to expressions using semiotic modalities to be presented. Design and production are difficult to separate because they are synergistic contexts presented in a certain semiotic mode. Fourth, focus on the distribution aspect, namely the layer of expression that needs to be stratified, then used to determine the characteristics presented. The modality factor in the distribution aspect is not very visible because it is independent of the design and production aspects in the discourse's presentation (Hermawan, 2013; Jewitt, 2008; Nina Nørgaard, 2009). In learning in tertiary institutions, the multimodal approach has several problems. The problem of the approach to learning, namely (1) the responsibility of the institution has not yet led to the preparation of students as learning analysts in the context of literary problems, especially the Educational Personnel Educator Institution; (2) based on the lecture syllabus, there are not many subject instructors who have adequate abilities in lecture learning, especially the use of a multimodal approach in learning literature, (3) references to literary learning approaches are still limited (Mochammad Bayu Firmansyah, 2018).

Based on a preliminary study of literature lectures in Literary Psychology lectures, it was found that a multimodal approach was needed to improve students' literary analysis capabilities. The results of document analysis and interviews with lecturers, students can reveal two fundamental problems which are then used as the basis for testing the effectiveness of the multimodal approach in learning, namely (1) the need to apply a multimodal approach in learning, and (2) the ability of students to be literary psychology. Through a preliminary study, it was found that Literary Psychology's ability is a competency that students need to have and is integrated in the lecture syllabus. However, in the aspect of a multimodal approach 
as an analytical approach to literary psychology it is found; (1) competencies developed in Literary Psychology courses are not yet based on an established and structured learning taxonomy, (2) the effectiveness of specific learning models is not yet available in developing literary psychology analytical skills, and (3) the development of analytical skills using a multimodal approach.

From the aspect of competency in the analysis of literary psychology, questionnaire analysis to students shows that students' literature psychology and attitudes of literary psychology need to be tested for their effectiveness. In the behavioral aspect of the Psychology of Literature analysis, as many as 58.82 percent of students prioritized understanding the meaning of discourse in the analysis, only 23.52 percent of students admitted to understanding discourse with various modalities (language, pictures, music, sound, and movement) in representing knowledge and meaning making; and only 17.64 percent of students tried to understand discourse by considering modalities (language, pictures, music, sound, and movement) in representing knowledge and meaning.

Based on the preliminary study results, this study aims to solve the problems of Literary Psychology lectures by testing the effectiveness of the multimodal approach in learning the Psychology of Literature course.

\section{METHOD}

The method used in this study is an experimental research method whose implementation uses a quasi experiment type. The effectiveness test is carried out on groups of students who are not involved in the testing process for prospective users. The steps of implementing the effectiveness test, namely (1) determining the control group and the experimental group, (2) conducting the pretest, (3) carrying out learning in the control and experimental class, (4) conducting the postest, and (5) analyzing the experimental test results. The effectiveness test process involved two classes of students from the Indonesian Language and Literature Study Program, PGRI Wiranegara University. 52 students were the test subjects. One class of students (class A) becomes the control group and one class (class B) becomes the experimental class. Random techniques carried out determination of the control and experimental groups. This technique was chosen because the two classes that were the subject of the experiment had the same characteristics. Class B was chosen as the experimental class and class A was chosen as the control class. The pretest was carried out in both classes at the beginning of the effectiveness test. After the pretest, learning was carried out in both classes.

The experimental class received literary psychology courses using a multimodal approach, while the control class received assignment-based literary psychology courses. The effectiveness test took place from September to December 2020 for 10 meetings. After the learning implementation series ended, the two classes were retested with a post-test. The post-test results were analyzed using 
different tests to conclude the effectiveness of the multimodal approach. The effectiveness test was designed with a quasi-experimental nonequivalent pretestpostest control group. This research's independent variable is literary psychology learning, while the dependent variable is the student learning outcomes. The experimental class learned using a multimodal approach, while the control class learned using task-based literary psychology. The experimental test design is described as follows.

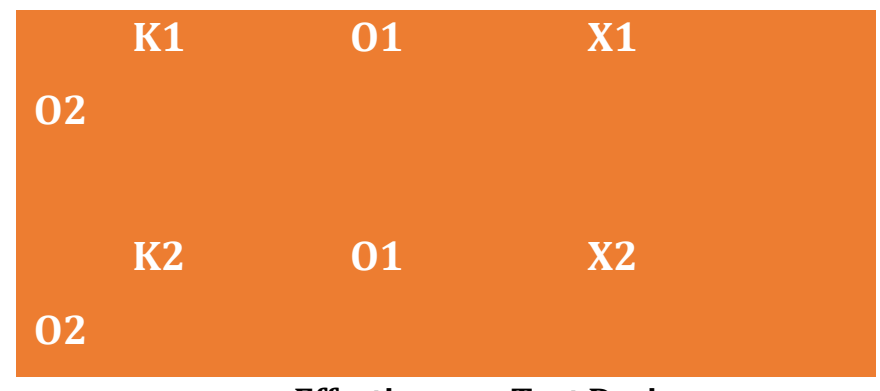

Effectiveness Test Design

\section{Information:}

K1 : Experimental group

K2 : Control group

$01 \quad$ : initial test score (pretest)

02 : final test score (posttest)

X1 : literary psychology learning using a multimodal approach

X2 : learning psychology literature on a task-based basis

\section{RESULTS AND DISCUSSION}

\section{Results of the Multimodal Approach Effectiveness Test in Learning}

The effectiveness test results were carried out to measure the effect of using a multimodal learning model for literary psychology courses. The presentation of effectiveness test results includes data normality test, data homogeneity test, and difference test ( $t$-test) described in the following explanation. 


\begin{tabular}{|c|c|c|c|c|c|}
\hline \multicolumn{6}{|c|}{ Descriptives } \\
\hline & Kelas & & & Statistic & Std. Error \\
\hline \multirow[t]{26}{*}{ NGain_Score_Persen } & \multirow[t]{13}{*}{ Eksperimen } & \multicolumn{2}{|l|}{ Mean } & 63,6579 & 1,18650 \\
\hline & & \multirow[t]{2}{*}{$95 \%$ Confidence Interval for Mean } & Lower Bound & 61,2143 & \\
\hline & & & Upper Bound & 66,1016 & \\
\hline & & $5 \%$ Trimmed Mean & & 63,4538 & \\
\hline & & Median & & 63,7562 & \\
\hline & & Variance & & 36,603 & \\
\hline & & Std. Deviation & & 6,05000 & \\
\hline & & Minimum & & 54,55 & \\
\hline & & Maximum & & 77,27 & \\
\hline & & Range & & 22,73 & \\
\hline & & Interquartile Range & & 9,91 & \\
\hline & & Skewness & & .242 & .456 \\
\hline & & Kurtosis & &,- 431 & .887 \\
\hline & \multirow[t]{13}{*}{ Kontrol } & Mean & & 36,7821 & 3,09236 \\
\hline & & \multirow[t]{2}{*}{$95 \%$ Confidence Interval for Mean } & Lower Bound & 30,4132 & \\
\hline & & & Upper Bound & 43,1509 & \\
\hline & & $5 \%$ Trimmed Mean & & 36,8501 & \\
\hline & & Median & & 38,9277 & \\
\hline & & Variance & & 248,629 & \\
\hline & & Std. Deviation & & 15,76799 & \\
\hline & & Minimum & & 9,09 & \\
\hline & & Maximum & & 63,89 & \\
\hline & & Range & & 54,80 & \\
\hline & & Interquartile Range & & 19,46 & \\
\hline & & Skewness & &,- 236 & .456 \\
\hline & & Kurtosis & &,- 600 & .887 \\
\hline
\end{tabular}

\begin{tabular}{|c|c|c|c|c|c|c|c|}
\hline \multicolumn{8}{|c|}{ Tests of Normality } \\
\hline & & \multicolumn{3}{|c|}{ Kolmogorov-Smirnov ${ }^{a}$} & \multicolumn{3}{|c|}{ Shapiro-Wilk } \\
\hline & Kelas & Statistic & $\mathrm{df}$ & Sig. & Statistic & df & Sig. \\
\hline \multirow[t]{2}{*}{ NGain_Score_Persen } & Eksperimen & .118 & 26 & $200^{*}$ & .961 & 26 & .414 \\
\hline & Kontrol & .085 & 26 & $.200^{*}$ & .961 & 26 & .407 \\
\hline
\end{tabular}

*. This is a lower bound of the true significance.

a. Lilliefors Significance Correction

The normality test used the Kolmogrov-Smirnov analysis model. Based on the normality test, it was found that: (1) the results of the experimental class data analysis had a significance value of 0.200 . This value is more significant than 0.05 $(0.200>0.05)$ so that the experimental class data can be concluded to be normally distributed. (2) The results of the control class data analysis have a significance value of 0.200 . This value is greater than $0.05(0.200>0.05)$, so it can be concluded that the control class data is normally distributed. Based on the results of the normality test, data analysis can be performed with parametric statistics.

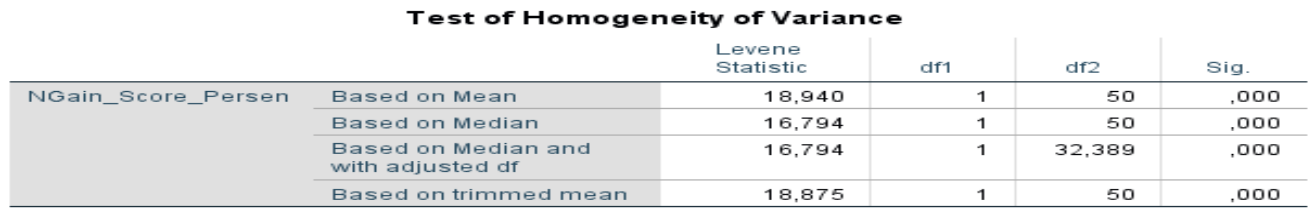

NGain_Score_Persen 
The homogeneity test results obtained the probability value of F-statistic $<$ Level of significance $=0.05$, so the data did not meet the homogeneity assumption. Thus, it can be stated that the research data has different variants (not homogeneous). However, because the homogeneity requirement is not absolute, the independent sample t-test can be continued.

\section{Posttest t-test results for the control class and experimental class}

The effectiveness of applying a multimodal approach to the psychology literature course was analyzed using the difference test. The analysis was carried out on the entire focus of literary psychology learning. The difference in the average post-test score between the experimental class and the control class was 26.875 . Based on statistical analysis, it is known that $t$ count is 8,114 and $p$ value $=0,000$. The statistical test results indicated a significant difference between the scores of the experimental class and the control class literature psychology learning $(p<0.05)$. These results indicate that the application of the multimodal learning model for the psychology of literature subject has a significant effect on students' critical reading skills. Thus, it can be concluded that the multimodal approach in literary psychology courses is effective in improving students' literary psychology analysis skills. The following will present the results of a statistical analysis of a multimodal approach for literary psychology courses.

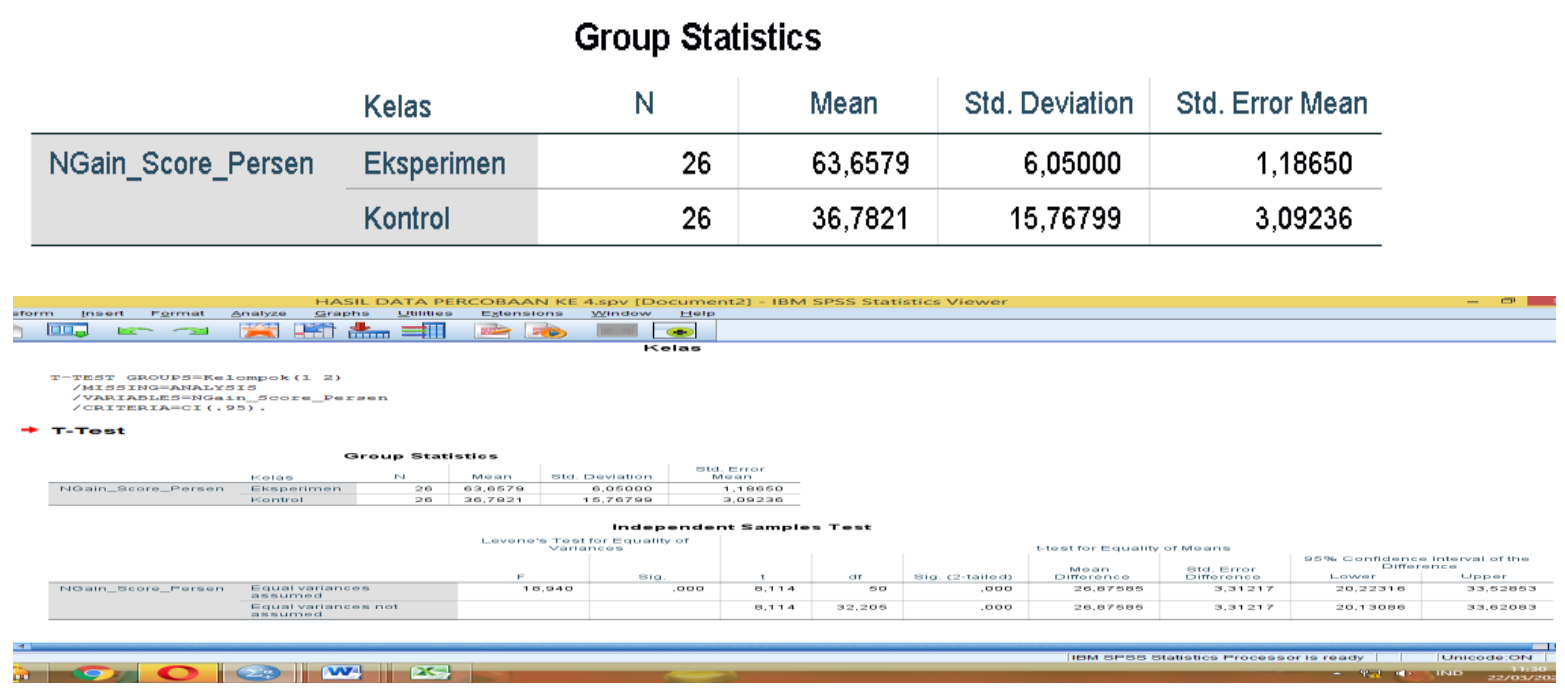

Source: Processed from the N-Gain Score Data with SPSS 23, 2020

Based on the results of the calculation of the difference between the two data averages presented in Table 4.10 and Table 4.11, it is known that Levene's Test for Equality of Variances column has a significance value of $0.000(p<0.05)$. This shows that the two variances are not the same, so the variance to compare the population average (t-test for Equality of Means) in the t-test test must be based on equal variance not assumed. At the equal variance not assumed, a t value of 8.114 was 
obtained and a significance level of Sig. (2-tailed) of $0.000<0.05, p=0.000$. These results indicate that $\mathrm{p}<0.05$, means that there is a significant difference between groups of students who get treatment using a multimodal approach. Thus, there is a significant difference in student learning outcomes between the experimental class with the multimodal approach compared to the control class with conventional methods.

The above analysis results show that Ho is rejected because of the significance level of Sig. (2-tailed) of $0.000<0.05$, while $\mathrm{H} 1$ was accepted because there was a significant difference between the increase in student learning outcomes in the experimental class and the control class.

\section{Multimodal Approach Combines Analysis Approach and Multimodal Competence in Learning}

Multimodal competence is an essential competency that students must master as the basic capital to take part in society in the era of the industrial revolution 4.0. Multimodal competence is the mastery of data literacy, technological literacy, and human literacy (Camilleri, 2021; Riset \& Tinggi, 2018). Data literacy is the ability to utilize data, analyze and utilize information (Big Data) in the digital world. Technological literacy is the ability to understand how machines work, technology applications (Coding, Artificial Intelligence, and Engineering Principles). Human literacy is the ability to communicate, humanities and designs. It is hoped that this multimodal competence can be achieved through the presentation of an integrated structure including: (1) the multimodal approach affective objectives, (2) the cognitive objectives of the multimodal approach, and (3) the psychomotor objectives of the multimodal approach. Literary psychology learning activities presented as a component of a multimodal approach contain the application of analysis in each learning focus. The application of this analysis aims to help students connect their understanding of the analytical approach with literary psychology analysis. Through the application of analysis, students are given learning scenarios, examples of objects of study, and multimodal literary psychology analysis steps. This is in line with opinion (Daryono, 2020; Freyn \& Ed, 2017; Janssen et al., 2015; Lee, 2014; Ryu \& Boggs, 2016; Wulan, 2017) who argues that effective learning is structured from a series of plans to reach students and assist in building lasting knowledge, skills and values.

The presentation of the multimodal approach developed in this study is a constructivist approach that is based on the principle of orientation to students towards concepts before they are studied so that their performance can be improved for students whose understanding is inadequate. The multimodal approach is directed at strengthening students' cognitive structure when learning new concepts or information and how that knowledge should be appropriately structured and understood. A multimodal approach through learning scenarios, examples of objects of study, and steps in multimodal psychological analysis of literature can equip students to prepare the meaning of the concepts to be studied and relate them to the concepts they already have. The multimodal literary 
psychology analysis ability developed in this study provides an opportunity for students to develop the skills and creativity they need. This is in line with the opinion (Mochammad Bayu Firmansyah, 2018; Mochammad Bayu Firmansyah et al., 2020) that students studying in tertiary institutions can have their capabilities optimized through comprehensive competences and multimodal competences to be able to compete for both among nations and partnerships with other nations. Therefore, multimodal literary psychology learning has a major role in science and technology and social life. Multimodal literary psychology learning also equips students in applying concepts and making the right decisions based on analysis and solutions independently or in groups. This study's multimodal approach aims to improve students' analytical skills by understanding various ways of representing knowledge and making meaning in discourse. The development of student analytical skills through a multimodal approach is carried out with a focus on discourse design by studying the contribution of semiotic sources deployed in various modalities (language, images, music, sound, and movement) as well as interaction and integration in the process of discourse coherence (Hermawan, 2013; Jewitt, 2008; Nina Nørgaard, 2009). The multimodal analytical approach considers how linguistic and visual choices meet the objectives of discourse, audience and context, and how those choices work together in the organization and develop information and ideas (Mochamad Bayu Firmansyah, 2018; Freyn \& Ed, 2017).

Multimodal competence which consists of the ability to represent knowledge and the making of meaning contained in the aspects of discourse, design aspects, production aspects, and distribution aspects are used as a systemic step in understanding discourse in various modalities (language, images, music, sound, and movement). Furthermore, these four aspects are applied to reveal modalities (language, images, music, sound, and movement). Students develop their abilities by revealing modalities through various objects of study. Thus, this multimodal approach provides a systemic step in assessing the modalities contained in the object of study (discourse).

The multimodal approach developed fosters students' multimodal competence in revealing knowledge representations and making meanings contained in the aspects of discourse, design aspects, production aspects, and distribution aspects. Multimodal literary psychology learning activities are carried out to reveal various modalities (language, images, music, sound, and movement). This learning process provides analytical and reflective experience to lead to the development of students' multimodal competences. This is in line with opinion (Cheng \& Liu, 2014; Coccetta, 2018; Mochammad Bayu Firmansyah, 2018; Mochammad Bayu Firmansyah et al., 2020; Freyn \& Ed, 2017; Hamdi, Syukrul, 2013; Lee, 2014; Wulan, 2017) that the multimodal competence of students can be developed through learning. In active learning, students create cognitive structures in their interactions with the environment. Through multimodal literary psychology 
learning students' analytical skills are developed. The development of students' multimodal abilities is carried out by applying multimodal literary psychology learning with a focus on the psychology study of authors as a type or as a person, a focus on creative process studies, a focus on type studies and the laws of psychology, and a focus on the impact of literature on readers. Furthermore, multimodal literary psychology learning directs students to express alternative ideas based on the multimodal analysis carried out.

The characteristics of the multimodal approach for literary psychology courses that are oriented to examine aspects of discourse, aspects of design, aspects of production, and aspects of distribution to develop student multimodal competence in this study are new findings that distinguish previous research and development. Research developed (Coccetta, 2018) focuses on multimodal texts that can improve student communication skills. The multimodal text is then used for learning materials. This is supported by trials that show that students perceive the multimodal approach developed as new and different from the usual learning approach. The novelty aspect of this multimodal approach is important for fostering student motivation. The learning model should equip students in preparing the meaning of the concepts to be studied and connect them with the concepts they already have.

\section{CONCLUSION}

The multimodal approach has been tested through the t-test to improve students' literary psychological analysis skills. The results of the effectiveness test showed a significant difference in students' psychological analysis abilities in general between the post-test scores of the control class and the experimental class $(\mathrm{p}=0.00<0.05)$. This shows that the two variances are not the same, so using the variance to compare the population average (t-test for Equality of Means) in the ttest test must be based on equal variance not assumed. At the equal variance not assumed, a t value of 8.114 was obtained and a significance level of Sig. (2-tailed) of $0.000<0.05, \mathrm{p}=0.000$. These results indicate that $\mathrm{p}<0.05$, means that there is $\mathrm{a}$ significant difference between groups of students who get treatment using a multimodal approach. Thus, there is a significant difference in student learning outcomes between the experimental class with the multimodal approach compared to the control class with conventional methods. The results of the above analysis show that Ho is rejected, because the significance level of Sig. (2-tailed) of 0.000 $<0.05$, while $\mathrm{H} 1$ was accepted because there was a significant difference between the increase in student learning outcomes in the experimental class and the control class. 


\section{REFERENCES}

Camilleri, P. (2021). Robot-proof: higher education in the age of artificial intelligence Robot-proof: higher education in the age of artificial intelligence. Journal of Education for Teaching, oo(00), 1-2. https://doi.org/10.1080/02607476.2018.1500792

Cheng, Y., \& Liu, W. (2014). A Multimodal Discourse Analysis of the Relationship between Pi and Richard the Tiger in the Movie Life of Pi. International Journal of Language and Literature, 2(4), 191-219. https://doi.org/10.15640/ijll.v2n4a11

Coccetta, F. (2018). Developing university students' multimodal communicative competence: Field research into multimodal text studies in English. System, 1-9. https://doi.org/10.1016/j.system.2018.01.004

Daryono. (2020). Menuju Manajemen berbasis Sekolah (M. Z. A. A. I. S.M (ed.); 1st ed.). Lembaga Academic \& Research Institute. https://books.google.co.id/books?id=qkDZDwAAQBAJ\&lpg=PP1\&ots=Pi qiVYxooR\&lr\&hl=id\&pg=PR2\#v=onepage \&q\&f=false

Firmansyah, Mochamad Bayu. (2018). MODEL PEMBELAJARAN DISKUSI BERBASIS PERILAKU BERLITERASI UNTUK KETERAMPILAN BERBICARA_BAYU_sept_2017. Edukasi Dan Sosial, 8(September 2017), 119-125. https://doi.org/10.31227/osf.io/ebx9j

Firmansyah, Mochamad Bayu. (2021). MULTIMODALITAS MODEL PEMBELAJARAN PSIKOLOGI SASTRA (T. D. P. Khatulistiwa (ed.); 2021st ed.). Delta Pijar Khatulistiwa.

https://scholar.google.com/scholar?cluster=12823019664925397591\& $\mathrm{hl}=$ en\&oi=scholarr

Firmansyah, Mochammad Bayu. (2018). Multimodal conception in learning. ISLLAC: Journal of Intensive Studies on Language, Literature, Art, and Culture, 2(1), 40-44. http://journal2.um.ac.id/index.php/jisllac/article/view/4140

Firmansyah, Mochammad Bayu, Siswanto, W., \& Priyatni, E. T. (2020). Multimodal Smartphone: Millennial Student Learning Style. Test Engineering \& Management, 82(January-February 2020), 9535-9545. https://scholar.google.co.id/scholar?hl=id\&q=Multimodal+Smartphone: +Millennial+Student+Learning+Style\&as_sdt=0

Freyn, A. L., \& Ed, D. (2017). Effects of a Multimodal Approach on ESL / EFL University Students' Attitudes towards Poetry. 8(8), 80-83. ISSN 2222-1735 (Paper) ISSN 2222-288X (Online)

Hamdi, Syukrul, A. (2013). DALAM PEMBELAJARAN MATEMATIKA MELALUI PENDEKATAN MULTI-MODAL STRATEGY ( MMS ). Prosiding, November, 978-979.

Hermawan, B. (2013). Multimodality: Menafsir Verbal. Bahasa \& Sastra, 13 No. 1 A. Janssen, F., Grossman, P., \& Westbroek, H. (2015). Facilitating decomposition and recomposition in practice-based teacher education: The power of modularity. Teaching and Teacher Education, 51, 137-146. https://doi.org/10.1016/j.tate.2015.06.009

Jewitt, C. (2008). Multimodality and Literacy in School Classrooms. Review of Research in Education, 32(1), 241-267. 
https://doi.org/10.3102/0091732X07310586

Lee, H. (2014). Using an arts-integrated multimodal approach to promote English learning: A case study of two Taiwanese junior college students HSIAOCHIEN LEE. English Teaching: Practice and Critique, 13(2), 55-75.

Montoro, R. (2015). Hoover, D. L., Culpeper, J., \&amp; O'Halloran, K. 2014. Digital Literary Studies. Corpus Approaches to Poetry, Prose, and Drama. International Journal of Corpus Linguistics, 20(1), 129-137. https://doi.org/10.1075/ijcl.20.1.07mon

Nina Nørgaard. (2009). The Semiotics of Typography in Literary Texts $\mid n A$ Multimodal Approach. 1979. http://www.sheltonography.com/resources/Articles/SemioticsofTypogr aphy.pdf

Riset, M., \& Tinggi, D. A. N. P. (2018). Pendidikan Tinggi Berkualitas: " Mendorong Kemajuan IPTEK, Inovasi, dan Daya Saing Bangsa di Era Revolusi Industri 4.0." $1-10$. http://repository.unpar.ac.id/bitstream/handle/123456789/5298/Oras i Dies UNPAR 63_2018_Moh.Nasir_Pendidikan tinggi berkualitasp.pdf?sequence $=1 \&$ isAllowed $=y$

Ryu, J., \& Boggs, G. (2016). Teachers' Perceptions about Teaching Multimodal Composition: The Case Study of Korean English Teachers at Secondary Schools. English Language Teaching, 9(6), 52. https://doi.org/10.5539/elt.v9n6p52

Wulan, A. P. (2017). Analisis Wacana Dan Edukasi: Semiotik Multimodal Kartun Indonesia " Adit Sopo Jarwo Episode Bakso Hilang "Vs Kartun Malaysia " Upin - Ipin Episode Ekosistem.” February, 1104-1117. 